\title{
The Impact of Working Capital Management on Profitability of Croatian Software Companies
}

\author{
Dina Korent* \\ Silvije Orsag **
}

\begin{abstract}
The idea that working capital management impacts profitability and risk of a company is generally accepted and in last 10-15 years has acquired a substantial interest. According$l y$, from the aspect of the measure of efficiency of working capital management, the objective of this paper is to evaluate working capital management impact on profitability of Croatian software companies. This impact was examined using descriptive and correlation as well as panel regression analysis for six-year period (2008-2013). The results show that after controlling for characteristics of the company and macroeconomic conditions working capital management significantly affects the profitability of Croatian software firms. Moreover, the results imply the existence of a nonlinear, concave quadratic relationship between the net working capital and return on assets. This suggest the existence of an optimal level of net working capital that balances costs and benefits and maximizes profitability of analysed companies.
\end{abstract}

Keywords: working capital management; net working capital; company's profitability; return on assets; Croatian software companies

JEL Classification: G30; G39

\section{Introduction}

Working capital management is one of the most important and sensitive aspects of overall financial management that requires careful consideration in all companies, regardless of their type or nature (Deloof, 2003; Dinku, 2013). The importance of working capital management primarily stems from the fact that most companies invest large amounts of money into current assets and use considerable amounts of cur-

\footnotetext{
${ }^{*}$ Dina Korent is at University of Zagreb, Faculty of Organization and Informatics, Varaždin, Croatia.

${ }^{* *}$ Silvije Orsag is at University of Zagreb, Faculty of Economics and Business, Zagreb, Croatia.
} 
rent liabilities as their source of financing (Deloof, 2003; Moyer, McGuigan, \& Kretlow, 2006; Brealey, Myers, \& Allen, 2011; Koralun-Bereźnicka, 2014). In addition, due to the dynamic nature of doing business, decision making about the investment in and financing of current assets and their components is frequent, repetitive, lengthy, and also very time-consuming for company managers (Richards \& Laughlin, 1980; Appuhami, 2008; Koralun-Bereźnicka, 2014). Furthermore, as a component of overall company strategy aimed at value creation, working capital management is important because of the significant influence it has on a company's liquidity (Kim \& Chung, 1990; Opler, Pinkowitz, Stulz, \& Williamson, 1999), solvency (Peel \& Wilson, 1996), profitability (Shin \& Soenen, 1998; García-Teruel \& Martínez-Solano, 2007; Afrifa, 2015) and, consequently, a company's worth (Kieschnick, Laplante, \& Moussawi, 2013; Baños-Caballero, García-Teruel, \& Martínez-Solano, 2014; Afrifa, 2015). Finally, it needs to be stressed that the significance of working capital management in a particular company depends on the surrounding macroeconomic conditions, which greatly influence its investments and the manner of their financing. As much as working capital management (i.e., liquidity management) is important in good times, it gains even more importance in bad times (Eljelly, 2004). Accordingly, economic crises emphasize the issues of business sector liquidity and put pressure on working capital positions (Enqvist, Graham, \& Nikkinen, 2012). Precisely for this reason, the current economic crisis, characterized by a significant decrease in sales, increased credit risk and increasingly difficult access to the banking system, has emphasized the importance of and renewed the interest in working capital management in companies all over the world (Chiou, Cheng, \& Wu, 2006; Şen \& Oruç, 2009; Archavli, Siriopoulos, \& Arvanitis, 2012; Enqvist et al., 2012).

Regardless of the macroeconomic and other conditions, working capital management should generally strive to achieve optimal levels of working capital components and optimal level of working capital that contributes the most to achieving the basic business goal of a company-the maximization of its net present value (Deloof, 2003). Since the stated goal implicitly entails maximizing the profitability and, at the same time, reaching the optimal level of liquidity of a company, it is understandable that the goal of entire working capital management is precisely the maximization of profitability, along with the simultaneous minimization of the risk of company's failure to meet its current liabilities or service its fixed assets (Raheman \& Nasr, 2007; Singhania, Sharma, \& Rohit, 2014). Although the maintenance of required or optimal levels of liquidity in conducting daily business activities is an immanent goal of working capital management (Eljelly, 2004), in the last 10-15 years it has increasingly been emphasized for its role in contributing to companies' profitability and success.

However, it is necessary to note that the mentioned dual goal of simultaneous maximal profitability and optimal liquidity often cannot be reached. According to numerous authors (Smith, 1980; Orsag, 2003; Raheman \& Nasr, 2007; Van Horne 
\& Wachowicz, 2008), and in terms of an assumed linear nature of the relationship between working capital management and the stated goals, those decisions that enhance profitability usually do not increase the chances of reaching the adequate level of liquidity. Conversely, those decisions that focus entirely on enhancing liquidity commonly tend to decrease profitability. Given the importance of each of these goals, reaching one goal at the cost of not reaching the other should not be an option and one should rather strive to strike a balance between the two (Raheman \& Nasr, 2007). This is exactly the reason why, among various strategies of working capital management, for the working capital management that strives to establish a balance between profitability and liquidity, a trade-off between profitability and liquidity needs to be established, as initially noted by K. Smith (1980).

According to the traditional view, the linearity of the relationship between a company's working capital management and its profitability entails that an aggressive strategy of working capital management would result in lower liquidity, but higher risk, profitability and market value of the company. Therefore, an aggressive strategy is considered to be a profit maximizing strategy of working capital management that represents what is usually meant when speaking about efficient working capital management, based on the principle of quick conversion of inventories and accounts receivables into money and on delays in making payments to suppliers, which shortens the money gap and increases its availability (Nobanee, 2009; Nwankwo \& Osho, 2010a; Enqvist et al., 2012).

However, the existence of both the positive and the negative impact of investing into working capital on a company's profitability suggests that the process of deciding about working capital investments involves making a compromise between the costs that rise and the costs that fall in accordance with the level of working capital investments (Baños-Caballero, García-Teruel, \& Martínez-Solano, 2012a; Baños-Caballero et al., 2014; Kwenda \& Holden, 2014; Afrifa, 2015). If the reasoning about the efficiency of the strategy of working capital management is widened-within the context of compromising between the positive and the negative impacts of investing into working capital-when the benefits of these investments are greater than their costs, additional working capital investments will have a positive effect on profitability and vice versa. In the first case, in the context of a positive impact on profitability, a conservative strategy of working capital management would be more efficient, whereas an aggressive strategy would be more efficient in the opposite situation.

Therefore, there is an optimal level of working capital that balances a company's costs and benefits, and maximizes profitability (Baños-Caballero et al., 2012a; Kwenda $\&$ Holden, 2014), while also achieving an adequate level of liquidity. Since any deviation from the optimal level of working capital investments, whether upwards or downwards, decreases a company's profitability, it follows that the efficient strategy of working capital management is simply an optimal strategy of working capital management. 


\section{Literature Review and Hypotheses}

The very idea that working capital management influences a company's profitability and risk is widely accepted (Brealey, Myers, \& Marcus, 2001; Brealey et al., 2011; Moyer et al., 2006; Brigham \& Daves, 2007; Van Horne \& Wachowicz, 2008) and in the last 10-15 years it has generated considerable interest. Accordingly, and in terms of finding the ultimate gauge of the efficiency of working capital management, numerous studies have been evaluating the management of working capital in an effort to determine its effect on companies' profitability and success.

Initial studies on this subject assume a linear relationship between these concepts and provide a strong statistical support for its significance. Due to the way in which the measures of working capital management influence a company's profitability, these studies can be divided into two groups: those more numerous, which point out the negative impact of working capital management and support an aggressive strategy of working capital management, and those that point out the positive impact of working capital management on companies' profitability and success, thus supporting a conservative strategy.

To date, the majority of empirical studies (Jose, Lancaster, \& Stevens, 1996; Shin \& Soenen, 1998; Deloof, 2003; Eljelly, 2004; Lazaridis \& Tryfonidis, 2006; Raheman \& Nasr, 2007; Ganesan, 2007; García-Teruel \& Martínez-Solano, 2007; Nobanee \& AlHajjar, 2009; Uyar, 2009; Zariyawati, Annuar, Taufiq, \& Rahim, 2009; Mathuva, 2010; Mohamad \& Saad, 2010; Silva, 2011; Archavli et al., 2012; Bhunia \& Das, 2012; Quayyum, 2012; Vural, Sökmen, \& Çetenak, 2012; Enqvist et al., 2012; Karadagli, 2012; Dinku, 2013; Singhania et al., 2014; Pais \& Gama, 2015) on the linear relationship between working capital management and profitability suggest the existence of a negative impact of working capital management on a company's profitability. This is in line with the thesis about a significantly positive impact of an aggressive strategy of working capital management. Although a greater number of empirical studies on the linear relationship between working capital management and profitability support the thesis that an aggressive strategy of working capital management positively influences a company's profitability, there is nevertheless a notable number of studies (Afza \& Nazir, 2008; Nazir \& Afza, 2009; Nobanee, 2009; Gill et al., 2010; Valipour, Shooshtarian, \& Ostovari, 2012; Ani, Okwo, \& Ugwunta, 2012; Charitou, Lois, \& Santoso, 2012; Akoto, Awunyo-Vitor, \& Angmor, 2013; Ahmad, Nadeem, \& Hamad, 2014; Angahar \& Alematu, 2014; Muscettola, 2014; Tahir \& Anuar, 2015) whose results suggest otherwise (Afza \& Nazir, 2008; Nazir \& Afza, 2009; Nobanee, 2009; Gill et al., 2010; Valipour et al., 2012; Charitou et al., 2012; Akoto et al., 2013; Ahmad et al., 2014; Angahar \& Alematu, 2014; Muscettola, 2014; Tahir \& Anuar, 2015).

When summarizing the results of various studies, one can generally conclude that the companies which invest less into working capital are more profitable. However, regardless of this general conclusion, there are certain contradictions which still 
remain in the research results regarding the linear relationship between the strategies of working capital management and profitability. Those contradictions could be attributed to the inconsistency and volatility of economic and other conditions in different countries and environments where the studies were conducted, the analysis of different industries, the differences in the distribution of company types within samples, different methods and approaches used in analysis, etc. Nevertheless, it is more viable and rational to conclude that these contradictions stem from the fact that working capital investments can have both positive and negative impacts on companies' profitability, which ultimately positively or negatively reflect on their owners' wealth (Gill et al., 2010).

With respect to the costs and benefits related to aggressive and conservative strategies of working capital management, as well as both positive and negative effects of working capital investments, one can assume that the relationship between working capital investments and a company's profitability is non-monotonic and non-linear, contrary to the initial assumption of linearity (Baños-Caballero et al., 2012a, 2014). Thus, if both the positive and the negative effects are strong enough, the relationship between working capital investments and profitability can be better described by a concave quadratic function. Unlike the majority of studies on the impact of working capital management on a company's profitability, which discuss the existence of an optimal level of working capital but nevertheless assume a linear relationship between the studied concepts, a very small number of recent studies (Silva, 2011; Baños-Caballero et al., 2012a; Baños-Caballero, García-Teruel, \& Martínez-Solano, 2012b; Baños-Caballero et al., 2014; Gomes, 2013; Afrifa, 2015; Pais \& Gama, 2015) on the aforementioned relationship assume and suggest its non-linearity. The results of these studies, except the one conducted by (Pais \& Gama, 2015), imply the existence of an optimal level of working capital which maximizes a company's profitability.

In accordance with the initial empirical studies of the impact of working capital management on a company's profitability, this paper first tests the hypothesis about the existence of a linear relationship between working capital management and the profitability of Croatian companies classified under Group 62.0 of the 2007 National Classification of Activities (NACE 2007, 62.0): Computer Programming, Consulting and Related Activities. Concretely, in line with the results of most studies, it is assumed that an aggressive strategy of working capital management has a significant positive impact on the profitability of analysed companies:

H1: Aggressive working capital management has a significant positive impact on the profitability of Croatian companies classified into the group of Computer Programming, Consulting and Related Activities.

Next, in line with the studies exploring the non-linear relationship, the second hypothesis assumes the existence of a concave quadratic relationship between working capital management and the profitability of Croatian companies classified into the group of Computer Programming, Consulting and Related Activities: 
H2: A significant concave quadratic relationship exists between working capital management and the profitability of Croatian companies classified into the group of Computer Programming, Consulting and Related Activities.

\section{Methodological Research Framework}

\section{Sample}

The research sample consists of Croatian companies classified into Group 62.0 of the 2007 National Classification of Activities (Computer Programming, Consulting and Related Activities) that were logged in Financial Agency's database, existing in the market and gaining revenues and profits during the period of 2008-2013. This group of companies was selected because of its importance in the context of growth and employment potentials, which additionally stresses the need for adequate working capital management in the said companies. Namely, according to the Industrial Strategy of the Republic of Croatia 2014-2020 (Republika Hrvatska, 2014), this sub-industry has been classified into a group of ,instigators“ of Croatian industry, along with 21 other sub-industries. This group is characterized by high exports, a positive EBITDA and significant employment numbers.

Financial Agency's data set provided the data on 3.287 companies. A balanced sample of 442 companies was formed after the companies that exited or entered the market between 2008 and 2013 were excluded from the analysis, along with those companies that had no employees for more than a year in that period (based on work hours), or had no revenue or profits. According to Financial Agency's data for 2008, the structure of these companies according to size is the following: 1 large company, 7 medium companies, 91 small companies and 343 micro companies.

\section{Data and Variables}

The data used in this research was that on Croatian companies from Group 62.0 (Computer Programming, Consulting and Related Activities), together with the macroeconomic data and variables. Company data included basic information about particular companies and certain quantitative (financial and non-financial) data that were needed for calculating variable measures at the company level which could be grouped into panel data. This basic data on the companies and the data used for calculating variable measures are secondary in nature and were obtained from the databases of the Financial Agency and Croatian Bureau of Statistics.

The selection of variable measures was determined by the availability of the data needed for their calculation and their frequency and significance in previous studies. Variable measures at the company level were defined for each company and each year 
in observation. Macroeconomic variables were defined on an annual level. A company's profitability was used as a dependent variable, measured by its return on assets (ROA), which represents the ratio of net income to total assets of a company multiplied by 100 . The independent variables that were used include the independent variables of primary interest and independent control variables. As the independent variables of primary interest, net working capital (wNOCTR) and its square value (wsqNOCTR) were used. The variable of net working capital was calculated as a relative figure-the percentage of net working capital in the total revenue of a company. Net working capital represents the difference between a company's current assets and current liabilities. To control for the other potential influences on a company's profitability, independent control variables are used, such as following internal control variables: the size of a company (SA), the age of a company (AGE), the growth of a company (GR), the percentage of fixed assets in a company's total assets (FATA), a company's financial leverage (L), a company's market power (MP), and the growth of real gross domestic product (GDPr) as external control variable. The size of a company is defined by its total assets, and its age is determined by the number of years that have passed since its founding. A company's growth was calculated as the percentage of annual changes in its total revenue, and a company's fixed asset investments were defined as the percentage of fixed assets in its total assets. Financial leverage equals the percentage of total liabilities in a company's total assets. Finally, a company's market power was defined as the percentage of its revenue in the total revenue of Group 62.0 (Computer Programming, Consulting and Related Activities). The data on the growth rates of real gross domestic product were taken from the database of Croatian Bureau of Statistics. Lastly, the variables with extreme values (ROA, the percentage of net working capital in relation to total revenue, revenue growth) were winsorized at the 1\% level (see (Eljelly, 2004; Baños-Caballero et al., 2014)).

\section{Methods and Regression Models Specification}

In addition to descriptive statistics which is primarily used to describe the sample, to test the impact of working capital management on the profitability of Croatian software companies the methods of inferential statistics, in particular correlation and panel regression analysis are used. In order to test the first (1) and the second (2) hypothesis the following dynamic panel regression models are estimated using Arellano-Bond estimator:

$$
\begin{aligned}
& R O A_{i t}=\beta_{0}+\beta_{1} * R O A_{i, t-1}+\beta_{2} * w N O C T R_{i t}+\sum_{k=3}^{7} \beta_{k} \\
& * \text { internal control variable }{ }_{i t}+\beta_{8} * G D P g r_{t}+\varepsilon_{i t} \\
& R O A_{i t}=\beta_{0}+\beta_{1} * R O A_{i, t-1}+\beta_{2} * w N O C T R_{i t}+\beta_{3} * w N O C T R_{i t}^{2} \sum_{k=4}^{8} \beta_{k} \\
& * \text { internal control variable }{ }_{i t}+\beta_{9} * G D P g r_{t}+\varepsilon_{i t}
\end{aligned}
$$


Dynamic specification of panel regression model and Arellano-Bond estimator are chosen for two reasons. First, as shown by the previous studies, is very likely that the profitability of the company is a dynamic category that persists. Second, taking into account theoretical findings of the subject area and previous studies it is evident that in models testing the impact of working capital management on the company's profitability, there may be a problem of endogeneity resulting from the existence of reverse causality and/or bias caused by omitted variables. In fact, not only working capital management affects the profitability of the company but also the profitability of the company may affect the management of working capital. Furthermore, there is a possibility of unobserved individual effects correlated with the independent variables in the model. The dynamic panel data model therefore seems appropriate considering that recognizes the dynamic nature of the company profitability and controls for potential endogeneity problem. The presence of the lagged dependent variable as independent variable in dynamic panel model allows to control for reverse causality and bias due to omitted variables. In this paper consequent endogeneity problem is solved using Arellano-Bond estimator which by first order differencing eliminates unobservable individual effects and includes in model internal instrumental variables that control for correlation between dependent variable difference and error term.

Finally, the coefficients of net working capital and the square of the latter allows us to determine the breakpoint in the net working capital-profitability relation as: $\frac{-\beta_{2}}{2 \beta_{3}}$. To verify our second hypothesis, this should be a maximum, since this would indicate that there is concave quadratic relationship between working capital and profitability and, hence, companies have an optimal net working capital level that maximizes their profitability.

\section{Empirical Results}

\section{Descriptive Statistics}

Table 1 (in Appendix) presents the results of descriptive statistics of variables that are included in the regression analysis. Since the distribution of variables is asymmetric, as a representative measure of central tendency we observe median. Results of descriptive statistics show that the median return on assets is $13.99 \%$, and median of percentage of net working capital in the total revenue of a company is $18.51 \%$. The median average size of company measured by its total assets is 837,009 Kunas indicating that $50 \%$ of companies in the sample have total assets less than the specified value, and $50 \%$ of them greater. Furthermore, the median age of the company is 11 years, and median annual revenue growth is $1.15 \%$. The median of percentage of fixed assets in total assets is $23.49 \%$. Percentage of fixed assets in total assets clearly 
indicates the importance of current assets, or gross working capital in the structure of total assets. The median value of financial leverage as one of the control variables is $43.41 \%$, and the median value of company's market power is $0.06 \%$. In the end, median of real gross domestic product growth rate is $1.4 \%$.

\section{Correlation Analysis}

Results of the correlation analysis are presented in Table 2 (in Appendix). The correlation results indicate a significant and positive association between return on assets on one side and net working capital and company's annual revenue growth on the other at 5\% significance level. The correlation between return on assets and company's size, company's age, percentage of fixed assets in a company's total assets, company's financial leverage, and company's market power is negative and significant at the same significance level. Net working capital is positively and significantly correlated with company's size, company's age and company's market power and negatively and significantly with percentage of fixed assets in a company's total assets and company's financial leverage. The correlation between the other control variables is evident from the correlation matrix.

\section{Regression Analysis}

Table 3 (in Appendix) shows the results of testing the first hypothesis for a total of 4 dynamic panel regression models: Arellano-Bond with default standard errors, Arellano-Bond with default standard errors and financial leverage as explanatory variable, Arellano-Bond with robust standard errors, Arellano-Bond with robust standard errors and financial leverage as explanatory variable. Results of testing the first hypothesis suggests that in the dynamic panel regression models that do not involve financial leverage as one of the explanatory variables, at the level of significance of 1 and 5\%, depending on the model, 1 percentage point increase of net working capital increases the company's profitability on average by 0.0652 percentage points. However, after financial leverage is introduced in the same models, relationship between net working capital and company's profitability has become inverse and high statistically significant at $0.1 \%$ level. Onwards, it can be concluded that increase in net working capital by one percentage point reduces the company's profitability by 0.128 percentage points. These results suggest that after inclusion of financial leverage as one of the explanatory variables H1 hypothesis cannot be rejected. The latter results are consistent with most previous researches conducted in different countries, times and samples (Richards \& Laughlin, 1980; Kieschnick et al., 2013; Baños-Caballero et al., 2014).

Results of testing second hypotheses are shown in Table 4 (in Apppendix). As for the first hypothesis 4 dynamic panel regression models have been estimated. After 
examining the results it is evident that the net working capital and its square statistically significantly affect company's return on assets. The regression coefficients for the net working capital and its square are statistically significant at $0.1,1$, and $5 \%$ respectively depending on the model. Consistent with predictions, results confirm a large and statistically significant concave quadratic relation between net working capital and company's profitability, since the coefficient on the square of net working capital is negative. These findings indicate that there is an optimal level of net working capital which maximizes company's profitability. According to the results of the observed models assessment that exclude financial leverage as explanatory variable optimal level of net working capital in the total revenue of a company amounts to $50.23 \%$. So, with other things being equal the maximum profitability of Croatian software companies is achieved when the company holds the net working capital equal to half of the value of company total revenue. In other words, the annual turnover ratio of net working capital is 2 , and software companies need to ensure financing of the net working capital for an average of 183.341 "days of sales". The optimal level of net working capital in the total revenue of a company according to the results of the evaluation of dynamic panel regression models that include financial leverage as explanatory variable is $-11.34 \%$. The above result indicates that the optimal level of net working capital after taking into account the company's financial leverage is achieved when the company realizes a deficit of working capital in the amount of about $11.34 \%$ of company's total revenue. The presented results suggest that one cannot reject the hypothesis $\mathrm{H} 2$.

\section{Discussion and Conclusion}

The aim of this paper is to analyse and provide empirical evidence about the nature of the relationship between working capital management and profitability of Croatian companies from Group 62.0 (Computer Programming, Consulting and Related Activities). The study was conducted on a balanced sample of 442 companies over a six-year period (2008 - 2013). The paper employs panel data regression analysis which allows for the unobserved heterogeneity and endogeneity control.

Results of testing the first hypothesis are twofold. Namely, results indicate that after controlling the impact of net working capital on company's profitability by the company's size, company's age, company's annual revenue growth, percentage of fixed assets in a company's total assets, company's market power and the growth of real gross domestic product, increase in the level of net working capital increases profitability of the company. The above speaks in favour of a conservative strategy of working capital management. However, after controlling the impact of net working capital on company's profitability for financial leverage also, relationship between net working capital and company's profitability becomes inverted, indicating that on 
average companies with lower levels of net working capital in relation to total revenue are more profitable.

Results of testing the second hypotheses point to the existence of significant concave quadratic relationship between working capital management and profitability of the company and suggest the existence of an optimal level of net working capital in relation to company's total revenue. In addition, net working capital below the optimal level increases profitability, and contrariwise, net working capital above the optimal level causes a reduction in company's profitability. Therefore, at net working capital levels below the optimal, the conservative strategy will predominate, and so an increase in net working capital will lead to increase in company's profitability. On the other hand, at net working capital levels above the optimal, the aggressive strategy will predominate, and so an increase in net working capital will lead to lower profitability. The presented results are consistent with the results obtained in following researches (Eljelly, 2004; Uyar, 2009; Nwankwo \& Osho, 2010b; Archavli et al., 2012).

Furthermore, the fact that after taking into account the financial leverage the optimal level of net working capital in relation to company's total revenue is achieved at a lower level, may be, in accordance with the pecking order theory. Companies with significant amounts of total liabilities in the structure of total assets, in order to avoid costly external financing choose more aggressive strategy of working capital management. This finding shows that the optimum is sensitive to financial constraints of the company.

There are several implications of this research that could be important and relevant for managers and for future research and development of the theory of working capital management. The results of this study suggest that managers in order to maximize profitability should aim at keeping as close as possible to the optimal net working capital level and try to avoid any deviation. In addition, the results of this study extend the research on the relevance of a good working capital management and suggests that the relationship between working capital management and company's profitability is concave quadratic, rather than linear. Accordingly it is recommended to use quadratic relationship in subsequent studies. 


\section{APPENDIX}

Table 1 Descriptive statistics

\begin{tabular}{|c|c|c|c|c|}
\hline \multicolumn{5}{|c|}{ ROA, Winsorized fraction .01} \\
\hline & Percentiles & Smallest & & \\
\hline $1 \%$ & .0714458 & .0714458 & & \\
\hline $5 \%$ & .3578106 & .0714458 & & \\
\hline $10 \%$ & .9746016 & .0714458 & Obs & 2,652 \\
\hline $25 \%$ & 4.115356 & .0714458 & Sum of Wgt. & 2,652 \\
\hline $50 \%$ & 13.99195 & & Mean & 21.60626 \\
\hline & & Largest & Std. Dev. & 21.64865 \\
\hline $75 \%$ & 32.73489 & 84.80907 & & \\
\hline $90 \%$ & 56.2661 & 84.80907 & Variance & 468.664 \\
\hline $95 \%$ & 67.65227 & 84.80907 & Skewness & 1.127754 \\
\hline $99 \%$ & 84.80907 & 84.80907 & Kurtosis & 3.395866 \\
\hline \multicolumn{5}{|c|}{ wNOCTR } \\
\hline & Percentiles & Smallest & & \\
\hline $1 \%$ & -65.23521 & -65.23521 & & \\
\hline $5 \%$ & -16.20768 & -65.23521 & & \\
\hline $10 \%$ & -4.49552 & -65.23521 & Obs & 2,652 \\
\hline $25 \%$ & 6.036894 & -65.23521 & Sum of Wgt. & 2,652 \\
\hline \multirow[t]{2}{*}{$50 \%$} & 18.50547 & & Mean & 22.76879 \\
\hline & & Largest & Std. Dev. & 29.55227 \\
\hline $75 \%$ & 35.88213 & 133.3934 & & \\
\hline $90 \%$ & 57.59187 & 133.3934 & Variance & 873.3368 \\
\hline $95 \%$ & 76.23523 & 133.3934 & Skewness & .7825544 \\
\hline $99 \%$ & 133.3934 & 133.3934 & Kurtosis & 5.630752 \\
\hline \multicolumn{5}{|c|}{ SA } \\
\hline & Percentiles & Smallest & & \\
\hline $1 \%$ & 43848 & 24596 & & \\
\hline $5 \%$ & 89801 & 27622 & & \\
\hline $10 \%$ & 125978 & 28087 & Obs & 2,652 \\
\hline $25 \%$ & 287587.5 & 32230 & Sum of Wgt. & 2,652 \\
\hline \multirow[t]{2}{*}{$50 \%$} & 834009 & & Mean & 4380527 \\
\hline & & Largest & Std. Dev. & $1.80 \mathrm{e}+07$ \\
\hline $75 \%$ & 2808363 & $3.05 \mathrm{e}+08$ & & \\
\hline $90 \%$ & 7988431 & $3.08 \mathrm{e}+08$ & Variance & $3.25 \mathrm{e}+14$ \\
\hline $95 \%$ & $1.63 \mathrm{e}+07$ & $3.42 \mathrm{e}+08$ & Skewness & 13.45312 \\
\hline $99 \%$ & $5.87 \mathrm{e}+07$ & $3.72 \mathrm{e}+08$ & Kurtosis & 227.2341 \\
\hline
\end{tabular}


Table 1 - Continued

\begin{tabular}{|c|c|c|c|c|}
\hline \multicolumn{5}{|c|}{ AGE } \\
\hline & Percentiles & Smallest & & \\
\hline $1 \%$ & 1 & 0 & & \\
\hline $5 \%$ & 2 & 0 & & \\
\hline $10 \%$ & 4 & 0 & Obs & 2,652 \\
\hline $25 \%$ & 7 & 0 & Sum of Wgt. & 2,652 \\
\hline \multirow[t]{2}{*}{$50 \%$} & 11 & & Mean & 9.997738 \\
\hline & & Largest & Std. Dev. & 4.408164 \\
\hline $75 \%$ & 13 & 18 & & \\
\hline $90 \%$ & 15 & 18 & Variance & 19.43191 \\
\hline $95 \%$ & 16 & 18 & Skewness & -.3498353 \\
\hline $99 \%$ & 17 & 18 & Kurtosis & 2.142408 \\
\hline \multicolumn{5}{|c|}{ GR, Winsorized fraction .01} \\
\hline & Percentiles & Smallest & & \\
\hline $1 \%$ & -59.99018 & -59.99018 & & \\
\hline $5 \%$ & -39.19073 & -59.99018 & & \\
\hline $10 \%$ & -27.8452 & -59.99018 & Obs & 2,210 \\
\hline $25 \%$ & -12.96599 & -59.99018 & Sum of Wgt. & 2,210 \\
\hline \multirow[t]{2}{*}{$50 \%$} & 1.149002 & & Mean & 6.688577 \\
\hline & & Largest & Std. Dev. & 38.2639 \\
\hline $75 \%$ & 16.44009 & 207.0829 & & \\
\hline $90 \%$ & 42.06457 & 207.0829 & Variance & 1464.126 \\
\hline $95 \%$ & 71.5806 & 207.0829 & Skewness & 2.36862 \\
\hline $99 \%$ & 207.0829 & 207.0829 & Kurtosis & 12.02309 \\
\hline \multicolumn{5}{|c|}{ FATA } \\
\hline & Percentiles & Smallest & & \\
\hline $1 \%$ & 0 & 0 & & \\
\hline $5 \%$ & .3344067 & 0 & & \\
\hline $10 \%$ & 1.838386 & 0 & Obs & 2,652 \\
\hline $25 \%$ & 7.567275 & 0 & Sum of Wgt. & 2,652 \\
\hline \multirow[t]{2}{*}{$50 \%$} & 23.49276 & & Mean & 31.50785 \\
\hline & & Largest & Std. Dev. & 27.33239 \\
\hline $75 \%$ & 51.04853 & 98.64194 & & \\
\hline $90 \%$ & 75.1458 & 99.55278 & Variance & 747.0593 \\
\hline $95 \%$ & 83.43553 & 99.95849 & Skewness & .6740268 \\
\hline $99 \%$ & 94.15246 & 100 & Kurtosis & 2.263976 \\
\hline \multicolumn{5}{|c|}{$\mathrm{L}$} \\
\hline & Percentiles & Smallest & & \\
\hline $1 \%$ & 3.771825 & .4276035 & & \\
\hline $5 \%$ & 8.688955 & .502475 & & \\
\hline $10 \%$ & 13.39734 & .9869909 & Obs & 2,652 \\
\hline $25 \%$ & 23.21751 & 1.551943 & Sum of Wgt. & 2,652 \\
\hline
\end{tabular}


Table 1 - Continued

\begin{tabular}{|c|c|c|c|c|}
\hline $50 \%$ & 43.41312 & & Mean & 45.72423 \\
\hline & & Largest & Std. Dev. & 26.39371 \\
\hline $75 \%$ & 66.12755 & 216.0139 & & \\
\hline $90 \%$ & 82.61897 & 221.3892 & Variance & 696.6279 \\
\hline $95 \%$ & 88.78722 & 233.834 & Skewness & .686634 \\
\hline $99 \%$ & 96.46149 & 238.4684 & Kurtosis & 5.147613 \\
\hline \multicolumn{5}{|c|}{ MP } \\
\hline & Percentiles & Smallest & & \\
\hline $1 \%$ & .0030964 & .0003889 & & \\
\hline $5 \%$ & .0072046 & .000498 & & \\
\hline $10 \%$ & .0111792 & .0008452 & Obs & 2,652 \\
\hline $25 \%$ & .0210067 & .0010523 & Sum of Wgt. & 2,652 \\
\hline \multirow[t]{2}{*}{$50 \%$} & .0607346 & & Mean & .2262443 \\
\hline & & Largest & \begin{tabular}{|l|} 
Std. Dev. \\
\end{tabular} & .635392 \\
\hline $75 \%$ & .1689731 & 7.764909 & & \\
\hline $90 \%$ & .4269506 & 7.788253 & Variance & .403723 \\
\hline $95 \%$ & .8687955 & 8.313305 & Skewness & 7.034982 \\
\hline $99 \%$ & 3.385443 & 9.296902 & Kurtosis & 67.33131 \\
\hline \multicolumn{5}{|c|}{ GDPr } \\
\hline & Percentiles & Smallest & & \\
\hline $1 \%$ & -7.4 & -7.4 & & \\
\hline $5 \%$ & -7.4 & -7.4 & & \\
\hline $10 \%$ & -7.4 & -7.4 & Obs & 2,652 \\
\hline $25 \%$ & -2.2 & -7.4 & Sum of Wgt. & 2,652 \\
\hline \multirow[t]{2}{*}{$50 \%$} & -1.4 & & Mean & -1.766667 \\
\hline & & Largest & Std. Dev. & 2.872049 \\
\hline $75 \%$ & -.3 & 2.1 & & \\
\hline $90 \%$ & 2.1 & 2.1 & Variance & 8.248666 \\
\hline $95 \%$ & 2.1 & 2.1 & Skewness & -.8277279 \\
\hline $99 \%$ & 2.1 & 2.1 & Kurtosis & 3.028596 \\
\hline
\end{tabular}

Source: Authors calculation 
Table 2 Correlation matrix

\begin{tabular}{|c|c|c|c|c|c|c|c|}
\hline & wROA & wNOCTR & SA & AGE & wGR & FATA & $\mathrm{L}$ \\
\hline wROA & 1.0000 & & & & & & \\
\hline wNOCTR & $0.2180^{*}$ & 1.0000 & & & & & \\
\hline SA & $-0.0866^{*}$ & $0.1459 *$ & 1.0000 & & & & \\
\hline AGE & $-0.0610 *$ & $0.0553^{*}$ & 0.0200 & 1.0000 & & & \\
\hline wGR & $0.2040 *$ & -0.0279 & -0.0024 & $-0.1363 *$ & 1.0000 & & \\
\hline FATA & $-0.1091 *$ & $-0.3282^{*}$ & $0.0512 *$ & -0.0091 & $-0.0438 *$ & 1.0000 & \\
\hline $\mathrm{L}$ & $-0.4967 *$ & $-0.5707^{*}$ & $-0.0436^{*}$ & $-0.0940 *$ & -0.0254 & 0.0307 & 1.0000 \\
\hline MP & $-0.0739 *$ & $0.0767 *$ & $0.8805^{*}$ & 0.0333 & 0.0283 & 0.0362 & -0.0220 \\
\hline \multirow[t]{2}{*}{ GDPr } & 0.0146 & 0.0230 & 0.0013 & 0.0066 & -0.0306 & $-0.4006^{*}$ & -0.0128 \\
\hline & MP & GDPr & & & & & \\
\hline MP & 1.0000 & & & & & & \\
\hline GDPr & 0.0000 & 1.0000 & & & & & \\
\hline
\end{tabular}

Source: Authors calculation

Table 3 Panel regression results for $\mathrm{H} 1$

\begin{tabular}{|c|c|c|c|c|}
\hline & (1) & (2) & (3) & (4) \\
\hline & AB1_default & AB1_default_with_L & AB1_robust & AB1_robust_with_L \\
\hline \multirow[t]{2}{*}{ L.wROA } & $0.0510 *$ & 0.0292 & 0.0510 & 0.0292 \\
\hline & $(2.03)$ & $(1.30)$ & $(1.77)$ & $(1.17)$ \\
\hline \multirow[t]{2}{*}{ wNOCTR } & $0.0652 * *$ & $-0.128 * * *$ & $0.0652 * *$ & $-0.128 * * *$ \\
\hline & $(3.27)$ & $(-6.22)$ & (2.08) & $(-4.06)$ \\
\hline \multirow[t]{2}{*}{ SA } & $-0.000000194 *$ & $-5.05 e-08$ & -0.000000194 & $-5.05 \mathrm{e}-08$ \\
\hline & $(-2.06)$ & $(-0.60)$ & $(-1.92)$ & $(-0.84)$ \\
\hline \multirow[t]{2}{*}{ AGE } & -0.143 & -0.0710 & -0.143 & -0.0710 \\
\hline & $(-0.69)$ & $(-0.38)$ & $(-0.54)$ & $(-0.30)$ \\
\hline \multirow[t]{2}{*}{ wGR } & $0.0991 * * *$ & $0.0912 * * *$ & $0.0991 * * *$ & $0.0912 * * *$ \\
\hline & (13.07) & $(13.41)$ & (9.44) & $(10.01)$ \\
\hline \multirow[t]{2}{*}{ FATA } & 0.00749 & $-0.0441^{* *}$ & 0.00749 & $-0.0441 * *$ \\
\hline & $(0.42)$ & $(-2.76)$ & $(0.43)$ & $(-2.61)$ \\
\hline \multirow[t]{2}{*}{ MP } & 1.570 & -0.579 & 1.570 & -0.579 \\
\hline & $(0.54)$ & $(-0.22)$ & $(0.56)$ & $(-0.30)$ \\
\hline \multirow[t]{2}{*}{ GDPr } & 0.172 & -0.217 & 0.172 & -0.217 \\
\hline & (1.17) & $(-1.64)$ & (1.19) & $(-1.65)$ \\
\hline \multirow[t]{2}{*}{$\mathrm{L}$} & & $-0.436^{* * *}$ & & $-0.436^{* * *}$ \\
\hline & & $(-19.56)$ & & $(-12.75)$ \\
\hline \multirow[t]{2}{*}{ _cons } & $20.32 * * *$ & $44.95 * * *$ & $20.32^{* * * *}$ & $44.95 * * *$ \\
\hline & $(7.72)$ & $(16.82)$ & $(6.02)$ & (11.54) \\
\hline $\mathrm{N}$ & 1768 & 1768 & 1768 & 1768 \\
\hline \multicolumn{5}{|c|}{$\mathrm{t}$ statistics in parentheses } \\
\hline \multicolumn{5}{|c|}{$* \mathrm{p}<0.05, * * \mathrm{p}<0.01, * * * \mathrm{p}<0.001$} \\
\hline
\end{tabular}

Source: Authors calculation 
Table 4 Panel regression results for $\mathrm{H} 2$

\begin{tabular}{|c|c|c|c|c|}
\hline & (1) & (2) & (3) & (4) \\
\hline & AB2_default & AB2_default_with_L & AB2_robust & AB2_robust_with_L \\
\hline \multirow[t]{2}{*}{ L.wROA } & $0.0544^{*}$ & 0.0323 & 0.0544 & 0.0323 \\
\hline & $(2.20)$ & $(1.44)$ & (1.92) & $(1.92)$ \\
\hline \multirow[t]{2}{*}{ wNOCTR } & $0.218^{* * *}$ & -0.0288 & $0.218 * * *$ & -0.0288 \\
\hline & $(8.24)$ & $(-1.04)$ & $(5.54)$ & $(-0.83)$ \\
\hline \multirow[t]{2}{*}{ wsqNOCTR } & $-0.00217 * * *$ & $-0.00127 * * *$ & $-0.00217 * * *$ & $-0.00127 * * *$ \\
\hline & $(-8.41)$ & $(-5.33)$ & $(-5.20)$ & $(-3.44)$ \\
\hline \multirow[t]{2}{*}{ SA } & -0.000000127 & $-1.88 \mathrm{e}-08$ & -0.000000127 & $-1.88 \mathrm{e}-08$ \\
\hline & $(-1.37)$ & $(-0.22)$ & $(-1.49)$ & $(-0.34)$ \\
\hline \multirow[t]{2}{*}{ AGE } & -0.0527 & -0.0222 & -0.0527 & -0.0222 \\
\hline & $(-0.26)$ & $(-0.12)$ & $(-0.20)$ & $(-0.09)$ \\
\hline \multirow[t]{2}{*}{ wGR } & $0.0895 * * *$ & $0.0859 * * *$ & 0.0895 *** & $0.0859 * * *$ \\
\hline & $(11.87)$ & $(12.58)$ & $(8.76)$ & $(9.49)$ \\
\hline \multirow[t]{2}{*}{ FATA } & 0.0151 & $-0.0370^{*}$ & 0.0151 & $-0.0370 *$ \\
\hline & $(0.87)$ & $(-2.32)$ & $(0.88)$ & $(-2.28)$ \\
\hline \multirow[t]{2}{*}{ MP } & 0.0337 & -1.358 & 0.0337 & -1.358 \\
\hline & $(0.01)$ & $(-0.52)$ & $(0.01)$ & $(-0.70)$ \\
\hline \multirow[t]{2}{*}{ GDPr } & 0.236 & -0.160 & 0.236 & -0.160 \\
\hline & $(1.63)$ & $(-1.21)$ & (1.63) & $(-1.23)$ \\
\hline \multirow[t]{2}{*}{$\mathrm{L}$} & & $-0.413 * * *$ & & $-0.413^{* * *}$ \\
\hline & & $(-18.26)$ & & $(-12.77)$ \\
\hline \multirow[t]{2}{*}{ _cons } & $18.91 * * *$ & $42.80 * * *$ & $18.91 * * *$ & $42.80 * * *$ \\
\hline & $(7.29)$ & $(15.93)$ & $(5.75)$ & (11.52) \\
\hline $\mathrm{N}$ & 1768 & 1768 & 1768 & 1768 \\
\hline \multicolumn{5}{|c|}{$\mathrm{t}$ statistics in parentheses } \\
\hline \multicolumn{5}{|c|}{$* \mathrm{p}<0.05, * * \mathrm{p}<0.01, * * * \mathrm{p}<0.001$} \\
\hline
\end{tabular}

Source: Authors calculation

\section{REFERENCES}

Afrifa, G. A. (2015). Net Working Capital, Cash Flow and Performance of UK SMEs. Cash Flow and Performance of UK SMEs (January 14, 2015).

Afza, T., \& Nazir, M. S. (2008). Working Capital Approaches and Firm's Returns in Pakistan. Social Sciences, 1, 25-36.

Ahmad, N., Nadeem, M., \& Hamad, N. (2014). Impact of working capital on corporate performance A case study from cement, chemical and engineering sectors in Pakistan. Arabian Journal of Business and Management Review, 3(7), 12-23.

Akoto, R. K., Awunyo-Vitor, D., \& Angmor, P. L. (2013). Working capital management and profitability: Evidence from Ghanaian listed manufacturing firms. Journal of Economics and International Finance, 5(9), 373-379.

Angahar, P. A., \& Alematu, A. (2014). Impact of working capital on the profitability of the Nigerian cement industry. European Journal of Accounting Auditing and Finance Research, 2(7), 17-30. 
Ani, W. U., Okwo, I. M., \& Ugwunta, D. O. (2012). Effects of Working Capital Management on Profitability: Evidence from the Topfive Beer Brewery Firms in the World. Asian Economic and Financial Review, 2(8), 966-982.

Appuhami, B. A. R. (2008). The Impact of Firms' Capital Expenditure On Working Capital Management: An Empirical Study Across Industries in Thailand. International Management Review, 4(1), 1-10.

Archavli, E., Siriopoulos, K., \& Arvanitis, S. (2012). Determinants of working capital management. Dohvaćeno Iz SSRN 2179907. http://doi.org/10.2139/ssrn.2179907

Baños-Caballero, S., García-Teruel, P. J., \& Martínez-Solano, P. (2012a). How does working capital management affect the profitability of Spanish SMEs? Small Business Economics, 39(2), 517-529. http://doi.org/10.1007/s11187-011-9317-8

Baños-Caballero, S., García-Teruel, P. J., \& Martínez-Solano, P. (2012b). Working capital requirement financing and Spanish SMEs performance. Fundación de Estudios Financieros.

Baños-Caballero, S., García-Teruel, P. J., \& Martínez-Solano, P. (2014). Working capital management, corporate performance, and financial constraints. Journal of Business Research, 67(3), 332338. Retrieved from http://www.sciencedirect.com/science/article/pii/S0148296313000180

Bhunia, A., \& Das, A. (2012). Affiliation between Working Capital Management and Profitability. Interdisciplinary Journal of Contemporary Research in Business, 3(9), 957-968.

Brealey, R. A., Myers, S. C., \& Allen, F. (2011). Principles of Corporate Finance (10th ed.). New York: McGraw-Hill/Irwin.

Brealey, R. A., Myers, S. C., \& Marcus, A. J. (2001). Fundamentals of Corporate Finance (3rd ed.). Boston, MA: McGraw-Hill Higher Education, divison of the McGraw-Hill Companies, Inc.

Brigham, E. F., \& Daves, P. R. (2007). Intermediate financial management (9th ed., Vol. 21). SouthWestern, Thomson Corporation. http://doi.org/10.1016/0890-8389(89)90100-5

Charitou, M., Lois, P., \& Santoso, H. B. (2012). The Relationship Between Working Capital Management and Firm's profitability: A Empirical Investigation For An Emerging Asian Country. International Business and Economics Research Journal, 11(8), 839-849.

Chiou, J.-R., Cheng, L., \& Wu, H.-W. (2006). The Determinants of Working Capital Management. The Journal of American Academy of Business, 10(1), 149-156. Retrieved from http://www. mendeley.com/research/determinants-working-capital-management/

Deloof, M. (2003). Does working capital management affect profitability of Belgian firms? Journal of Business Finance and Accounting, 30(3-4), 573-587. http://doi.org/10.1111/1468-5957.00008

Dinku, T. (2013). Impact of Working Capital Management on Profitability of Micro and Small Enterprises in Ethiopia : The Case of Bahir Dar City Administration. International Journal of Accounting and Taxation, 1(1), 15-24. http://doi.org/10.15640/ijat

Eljelly, A. M. A. (2004). Liquidity - profitability tradeoff: An empirical investigation in an emerging market. International Journal of Commerce and Management, 14(2), 48-61.

Enqvist, J., Graham, M., \& Nikkinen, J. (2012). The Impact of Working Capital Management on Firm Profitability in Different Business Cycles: Evidence From Finland the Impact of Working Capital Management on Firm Profitability in Different Business Cycles: Evidence From Finland. International Business and Finance, 32(August), 36-49. http://doi.org/doi:10.1016/j. ribaf.2014.03.005

Ganesan, V. (2007). An analysis of working capital management efficiency in telecommunication equipment industry. Rivier Academic Journal, 3(2), 1-10. Retrieved from http://www.rivier. edu/journal/ROAJ-Fall-2007/J119-Ganesan.pdf

García-Teruel, P. J., \& Martínez-Solano, P. (2007). Effects of working capital management on SME profitability. International Journal of Managerial Finance, 3(2), 164-177. http://doi. org/10.1108/17439130710738718 
Gill, A., Biger, N., Mathur, N., Palmer, S., Street, W. H., \& Vb-k, B. C. (2010). The Relationship Between Working Capital Management And Profitability: Evidence From The United States. Business and Economics Journal, 2010, 1-9.

Gomes, D. F. N. (2013). How does Working Capital Management affect Firms' Profitability? - Evidence from Portugal. School of Economics \& Management, Lisboa. Retrieved from Masther thesis

Jose, M. L., Lancaster, C., \& Stevens, J. L. (1996). Corporate Return and Cash Conversion Cycle. Journal of Economics and Finance, 20(1), 33-46.

Karadagli, E. C. (2012). The Effect of Working Capital Management on the Profitability of Turkish SMEs. British Jorunal Od Economics, Finance and Management Sciences, 5(2), 36-44.

Kieschnick, R., Laplante, M., \& Moussawi, R. (2013). Working Capital Management and Shareholders' Wealth. Review of Finance, 17(5), 1827-1852. http://doi.org/10.1093/rof/rfs043

Kim, J. H., \& Chung, K. H. (1990). An integrated evaluat ion of investment in inventory a nd credit: a cash flow approach. Journal of Business Finance and Accounting, 17(3), 381-390.

Koralun-Bereźnicka, J. (2014). On the Relative Importance of Corporate Working Capital Determinants : Findings from the EU Countries. Contemporary Economics, 8(4), 415-434. http://doi. org/10.5709/ce.1897-9254.154

Kwenda, F., \& Holden, M. (2014). Determinants of Working Capital Investment in South Africa: Evidence from Selected JSE- Listed Firms. Journal of Economics and Behavioral Studies, 6(7), $569-580$.

Lazaridis, I., \& Tryfonidis, D. (2006). Relationship Between Working Capital Management and Profitability of Listed Companies in the Athens Stock Exchange. Journal of Financial Management \& Analysis, 19(1), 26-35.

Mathuva, D. M. (2010). The Influence of Working Capital Management Components on Corporate Profitability: A Survey on Kenyan Listed Firms. Research Journal of Business Management. http://doi.org/10.3923/rjbm.2010.1.11

Mohamad, N. E. A. B., \& Saad, N. B. M. (2010). Working Capital Management: The Effect of Market Valuation and Profitability in Malaysia. International Hournal of Business and Management, 5(11), 140-147.

Moyer, R. C., McGuigan, J. R., \& Kretlow, W. J. (2006). Contemporary Financial Management (10th ed.). Mason, OH: South-Western, Thomson Corporation.

Muscettola, M. (2014). Cash Conversion Cycle and Firm's Profitability: An Empirical Analysis on a Sample of 4.226 Manufacturing SMEs of Italy. International Journal of Business and Management, 9(5), 25-35. http://doi.org/10.5539/ijbm.v9n5p25

Nazir, M. S., \& Afza, T. (2009). Impact of Aggressive Working Capital Management Policy on Firms ' Profitability. Journal of Applied Finance, 15(8), 19-31. http://doi.org/10.5897/AJBM11.326

Nobanee, H. (2009). Working Capital Management and Firm's Profitability: An Optimal Cash Conversion Cycle. Dohvaćeno Iz SSRN 147123. http://doi.org/10.2139/ssrn.1471230

Nobanee, H., \& AlHajjar, M. (2009). A Note on Working Capital Management and Corporate Profitability of Japanese Firms. Electronic Copy Available at: Http://ssrn. Com/abstract, 1433243. Retrieved from http://papers.ssrn.com/sol3/papers.cfm?abstract_id=1433243

Nwankwo, O., \& Osho, G. (2010a). An empirical analysis of corporate survival and growth: Evidence from efficient working capital management. International Journal of Scholarly ..., 12(1), 1-13. Retrieved from http://www.nationalforum.com/Electronic Journal Volumes/Nwankwo, Odi An Empirical Analysis of Corporate Survival and Growth IJSAID V12 N1 2010.pdf

Nwankwo, O., \& Osho, G. S. (2010b). An empirical analysis of corporate survival and growth: Evidence from efficient working capital management. International Journal of Scholarly Academic Intellectual Diversity, 12(1), 1-13. Retrieved from http://www.nationalforum.com/ 
Electronic Journal Volumes/Nwankwo, Odi - An Empirical Analysis of Corporate Survival and Growth IJSAID V12 N1 2010.pdf

Opler, T., Pinkowitz, L., Stulz, R., \& Williamson, R. (1999). The determinants and implications of corporate cash holdings. Journal of Financial Economics, 52(1), 3-46.

Orsag, S. (2003). Vrijednosni papiri. (M. Ivanišević, Ed.). Sarajevo: Revicon.

Pais, M. A., \& Gama, P. M. (2015). Working capital management and SMEs profitability : Portuguese evidence. International Journal of Managerial Finance, 11(3), 341-358. http://doi. org/10.1108/IJMF-11-2014-0170

Peel, M. J., \& Wilson, N. (1996). International Small Business Journal. International Small Business Journal, 14(2), 52-68. http://doi.org/10.1177/0266242696142004

Quayyum, S. T. (2012). Relationship between Working Capital Management and Profitability in Context of Manufacturing Industries in Bangladesh. International Journal of Business and Management, 7(1), 58-70. http://doi.org/10.5539/ijbm.v7n1p58

Raheman, A., \& Nasr, M. (2007). Working Capital Management And Profitability - Case Of Pakistani Firms, 3(1), 279-300.

Republika Hrvatska, M. G. (2014). Industrijska strategija Republike Hrvatske 2014. - 2020. Zagreb.

Richards, V. D., \& Laughlin, E. J. (1980). A Cash Conversion Cycle Approach to Liquidity Analysis. Financial Management (1972). Spring80, 9(1), 32-38. http://doi.org/10.2307/3665310

Şen, M., \& Oruç, E. (2009). Relationship between Efficiency Level of Working Capital Management and Return on Total Assets in Ise. International Journal of Business and Management, 4(10), $109-114$.

Shin, H., \& Soenen, L. (1998). Efficiency of working capital management and corporate profitability. Financial Practice and Education, 8(2), 37-45.

Silva, S. M. S. F. N. (2011). Effects of working capital management on the profitability of Portuguese manufacturing firms. Universidade do Minho, Braga.

Singhania, M., Sharma, N., \& Rohit, J. Y. (2014). Working capital management and profitability: evidence from Indian manufacturing companies. Decision, 41(3), 313-326. http://doi. org/10.1007/s40622-014-0043-3

Smith, K. (1980). Profitability versus Liquidity Tradeoffs in working capital management. Readings on the Management of Working Capital, 549-562.

Tahir, M., \& Anuar, M. B. A. (2015). The determinants of working capital management and firms performance of textile sector in pakistan. Quality \& Quantity, 1-14. http://doi.org/10.1007/ s11135-015-0166-4

Uyar, A. (2009). The Relationship of Cash Conversion Cycle with Firm Size and Profitability : An Empirical Investigation in Turkey. International Research Journal of Finance and Economics, 24(24), 187-193.

Valipour, H., Shooshtarian, Z., \& Ostovari, E. (2012). Relationship between Working Capital, Operating Cash Flows and Operating Income: Empirical Evidences from Listed Firms in Tehran Stock Exchange. Asian Economic and Financial Review, 2(1), 20-29.

Van Horne, J. C., \& Wachowicz, J. M. (2008). Fundamentals of Financial Management (13th editi). Harlow: Prentice Hall Inc.

Vural, G., Sökmen, A. G., \& Çetenak, E. H. (2012). Affects of Working Capital Management on Firm 's Performance : Evidence from Turkey. International Journal of Economics and Financial Issues, 2(4), 488-495. Retrieved from www.econjournals.com

Zariyawati, M. A., Annuar, M. N., Taufiq, H., \& Rahim, A. S. A. (2009). Working capital management and corporate performance: Case of Malaysia. Journal of Modern Accounting and Auditing, $5(11), 47-54$. 
